УДК 657.1.011

DOI 10.35433/ISSN2410-3748-2019-1(24)-7

В.Я. Плаксіснко, д.е.н., професор, завідувач кафедри бухгалтерського обліку

К.В. Черненко, к.е.н., ст. викладач кафедри бухгалтерського обліку

Полтавська державна аграрна академія

\title{
ЕЛЕКТРОННИЙ (БЕЗПАПЕРОВИЙ) ДОКУМЕНТООБІГ. ЕЛЕКТРОННИЙ ЦИФРОВИЙ ПІДПИС
}

В статті розглянуто переваги електронного безпаперового документообігу, визначено основні цілі автоматизачії обліку. Розкрито структурні елементи

безпаперової бухгалтерії в умовах розвитку ринку. Без надійної системи документообігу жоден суб'єкт господарювання не може якісно та ефективно функціонувати, оскільки оперативність, надійність та віддача всього господарського механізму залежсть від об'єктивності та своєчасності інформаційного забезпечення.

Обтрунтовано, щуо особливо важливе значення безпаперова бухгалтерія має для підприємств щзо трунтуються на багатопрофільності їх діяльності, а відповідно широкому різноманіттю форм облікової документації, та розповсюдженості у просторі, щуо зумовлює необхідність уникання складнощуів у функиіонуванні інфраструктури.

Встановлено, щз впровадження безпаперової бухгалтерії сприяє значному підвищенню ефективності організачії облікового прочесу суб 'єкта господарювання на інновачійній основі. Електронний документообіг забезпечує поетапне системне фіксування, обробку, та архіващію інформащії про здійснені господарські операчії на підприємстві.

Ключові слова: облік, автоматизація обліку, програмні бухгалтерські продукти, документ, електронний документ, інформаційні системи.

\section{ELECTRONIC (SECURITY) DOCUMENTARY COURSES. ELECTRONIC DIGITAL SIGNATURE}

The article examines advantages of electronic paperless document flow, it defines basic goals of accounting automation. The structural elements of paperless accounting are shown in the conditions of market development. Without a reliable system of document flownone of subjects of economic management can qualitatively and effectively function as long as an operationability, reliability and return of all economic mechanism depends of objectivity and timelinessof dataware.

It is proved that exceptionally important value a paperless accounting has for enterprises that are based on multitasking of their activity, as they have a wide variety of forms of accounting records that are diffused in space. All this predetermines the necessity of complication avoidance for functioning of infrastructure.

(C) Плаксієнко В.Я., Черненко К.В. 
It is established that implementation of paperless accounting assist sth econsiderable increase of efficiency of accounting process organization of subject of economic management on innovative basis. Electronic document flow provides the stage-by-stage system fixing, processing and archivation of information about accomplished economic operations at the enterprise.

Keywords: account, automation of account, software book-keeping products, document, electronic document, informative systems.

Постановка проблеми. Система бухгалтерського обліку вже більше 25 років перебуває в стадії активного реформування. В період ринкових відносин фінансова результативність роботи будь-якої організації в більших випадках залежить від самого вибору ведення бухгалтерського обліку, переходу з паперового документообороту до електронного.

Ефективна організація процесів документування та документообігу на підприємстві сьогодні є нагальною потребою. Вітчизняні суб'єкти господарювання, які залишилися у бізнесі, незважаючи на труднощі економічного та політичного характеру останніх десятиріч, визнали необхідність налагодження на підприємстві належного рівня планування, обліку та контролю всіх наявних ресурсів водночас із розумінням того, що діяльність підприємства має бути прозорою. Усе це обумовило підвищену зацікавленість у налагодженні системи, яка генерує, трансформує, передає та зберігає якісні інформаційні ресурси для прийняття зважених рішень стосовно оперативного управління та стратегічного планування діяльності суб’єкта господарювання. Такі завдання вирішуються в сучасній системі документообігу господарської діяльності, зокрема питання організації, уніфікації, напрямів удосконалення та перспективного розвитку потребують подальших досліджень, ураховуючи підвищений інтерес до них із боку науковців.

Аналіз останніх досліджень і публікацій. Питанням, пов'язаним 3 теорією та практикою щодо переходу з паперового документообороту до електронного, присвятили наукові праці провідні вітчизняні науковці: Ф.Ф. 
Бутинець, I.М. Назаренко, О.С. Кішка, В.О. Осмятченко, М.С. Пушкар, В.Д. Шквір, С.В. Івахненко та ін.

Автори досліджують концептуальні основи організації безпаперової бухгалтерії іï призначення, характеристика складових та ключових аспектів. Взаємозв'язок між предметом і методом бухгалтерського обліку в умовах застосування інформаційних технологій.

Формування цілей статті. Метою дослідження є визначення змісту i ролі обліково-аналітичного забезпечення управління підприємством, методів ефективного застосування програмного забезпечення для планування, аналізу і оптимізації фінансово-економічної діяльності.

Виклад основного матеріалу. Електронний документ є основним об’єктом будь-якої системи електронного документобігу.

Електронний документ - документ, інформація в якому зафіксована у вигляді електронних даних, включаючи обов'язкові реквізити документа. Електронний документ може бути створений, переданий, збережений i перетворений електронними засобами у візуальну форму. Візуальною формою подання електронного документа є відображення даних, які він містить, електронними засобами або на папері у формі, придатній для приймання його змісту людиною.

Електронний документ характеризується змістом, контекстом та структурою.

Зміст електронного документа - це текстові та графічні частини, що складають документ.

Контекст електронного документа - інформація про зв'язки задокументованої інформації з фізичними або юридичними особами та іншими документами.

Структура електронного документа:

внутрішня структура - це структура змістовної частини документа;

() Плаксієнко В.Я., Черненко К.В. 
зовнішня структура - це структура середовища, в якому існує електронний документ (носій інформації, формат файла тощо).

Електронний документ визначається своїми метаданими. Метадані це дані, що пов'язані та стосуються електронного документа, містять інформацію про його соціальну визначеність та розуміння змісту, контексту, структури. Метадані електронного документа мають елементи юридичних, ділових, організаційних, процедурних доказів цілісності електронного документа та його автентичності для авторів, користувачів та дослідників. Метадані $є$ обов'язковим елементом процесу зберігання електронного документа.

Юридична сила електронного документа не може бути заперечена виключно через те, що він має електронну форму. Допустимість електронного документа як доказу не може заперечуватися виключно на підставі того, що він має електронну форму.

Електронний документ не може бути застосовано як оригінал:

- свідоцтва про право на спадщину;

- документа, який відповідно до законодавства може бути створений лише в одному оригінальному примірнику, крім випадків існування централізованого сховища оригіналів електронних документів;

- в інших випадках, передбачених законом.

В Україні використання електронних документів та цифрових підписів регулюється на підставі Закону України «Про електронні документи та електронний документообіг»та Закону України «Про електронний цифровий підпис» [1].

Пріоритетними цілями організації безпаперової бухгалтерії на підприємстві є:

- автоматизоване фіксування господарських операцій в бухгалтерському і податковому обліку; 
- автоматизоване формування звітності підприємства (фінансової та податкової);

- організація безпаперового обліку на підприємстві;

- оперативне надання зовнішнім та внутрішнім стейкхолдерам повної, неупередженої та достовірної обліково-економічної інформації для оцінки показників діяльності підприємства та визначення управлінських ініціатив.

Завданнями організації безпаперової бухгалтерії є забезпечення:

1) своєчасної, повної, достовірної реєстрації господарських операцій, здійснюваних на підприємстві, в інформаційній системі;

2) процесу збирання, автоматизованої обробки, архівування інформації про господарські операції підприємства;

3) оптимізації процесу документообігу;

4) автоматизованої систематизації та узагальнення показників, які характеризують діяльність підприємства за звітний період (місяць, квартал, рік) у відповідних формах фінансової звітності;

5) складання звітності (декларацій, звітів) за податковий період та їх подання в електронному вигляді в режимі он-лайн у відповідні контролюючі органи;

6) експорту бухгалтерських документів з інформаційної системи до текстових процесорів;

7) реалізації контрольних процедур в автоматизованому режимі;

8) інформаційної безпеки;

9) деталізованої інформаційної бази для проведення комплексної економічної діагностики підприємства;

10) формування структурованої обліково-інформаційної платформи для розробки управлінських рішень.

Основними функціями безпаперового обліку виступають: 
1) інформаційна (оперативний доступ, пошук, своєчасне надання повної, правдивої інформації про фактичний стан господарської діяльність підприємства зовнішнім та внутрішнім користувачам);

2) аналітична (оцінка результатів фінансово-господарської діяльності підприємства на основі даних первинного, зведеного, аналітичного обліку з метою ідентифікації зовнішніх, внутрішніх ризиків та визначення напрямів розвитку суб'єкта господарювання в стратегічній перспективі);

3) контрольна (забезпечення здійснення контролю за об'єктами бухгалтерського обліку в процесі виконання господарських операцій 3 метою запобігання, профілактики зловживань та шахрайства);

4) комунікаційна (забезпечення формування та узагальнення інформації зовнішнім та внутрішнім користувачам);

5) прогнозна (визначення перспектив розвитку підприємства на основі даних бухгалтерського обліку та показників фінансової звітності) [2].

Кабінет Міністрів України та інші органи виконавчої влади в межах повноважень, визначених законом, реалізують державну політику електронного документообігу.

Державне регулювання у сфері електронного документообігу спрямовано на:

- реалізацію єдиної державної політики електронного документообігу;

- забезпечення прав і законних інтересів суб'єктів електронного документообігу;

- нормативно-правове забезпечення технології оброблення, створення, передавання, одержання, зберігання, використання та знищення електронних документів.

(C) Плаксієнко В.Я., Черненко К.В. 
Юридична сила електронного документа не може бути заперечена виключно через те, що він має електронну форму.

Допустимість електронного документа як доказу не може заперечуватися виключно на підставі того, що він має електронну форму.

Електронний документ не може бути застосовано як оригінал:

1) свідоцтва про право на спадщину;

2) документа, який відповідно до законодавства може бути створений лише в одному оригінальному примірнику, крім випадків існування централізованого сховища оригіналів електронних документів;

3) в інших випадках, передбачених законом.

Нотаріальне посвідчення цивільно-правової угоди, укладеної шляхом створення електронного документа (електронних документів), здійснюється у порядку, встановленому законом.

Оригіналом електронного документа вважається електронний примірник документа 3 обов'язковими реквізитами, у тому числі 3 електронним підписом автора або підписом, прирівняним до власноручного підпису відповідно до Закону України "Про електронні довірчі послуги"

У разі надсилання електронного документа кільком адресатам або його зберігання на кількох електронних носіях інформації кожний 3 електронних примірників вважається оригіналом електронного документа.

Якщо автором створюються ідентичні за документарною інформацією та реквізитами електронний документ та документ на папері, кожен 3 документів є оригіналом і має однакову юридичну силу.

Оригінал електронного документа повинен давати змогу довести його цілісність та справжність у порядку, визначеному законодавством; у визначених законодавством випадках може бути пред'явлений у візуальній формі відображення, в тому числі у паперовій копії.

(C) Плаксієнко В.Я., Черненко К.В. 
Електронна копія електронного документа засвідчується у порядку, встановленому законом.

Копією документа на папері для електронного документа $є$ візуальне подання електронного документа на папері, яке засвідчене в порядку ( 6802004-п ), встановленому законодавством [3].

Електронний документообіг здійснюється відповідно до законодавства України або на підставі договорів, що визначають взаємовідносини суб'єктів електронного документообігу.

Використання електронного документа у цивільних відносинах здійснюється згідно із загальними вимогами вчинення правочинів, встановлених цивільним законодавством.

Державне регулювання у сфері електронного документообігу спрямовано на вирішення низки ключових питань:

- по-перше, реалізації єдиної державної політики електронного документообігу;

- по-друге, забезпеченні прав і законних інтересів суб'єктів електронного документообігу;

- по-трете, нормативно-правовому забезпеченні технології оброблення, створення, передавання, одержання, зберігання, використання та знищення електронних документів.

Інші положення вказаного закону характеризують електронний документ (інтерпретацію; правовий статус); засади електронного документообігу (відправлення, передавання електронних документів; одержання електронних документів; перевірку цілісності електронного документу; зберігання та архів електронних документів); організацію електронного документообігу (організацію електронних документів; обіг електронних документів, що містять інформацію з обмеженим доступом, права та обов'язки суб'єктів електронного документообігу) [4].

(C) Плаксієнко В.Я., Черненко К.В. 
При підписанні електронного документу його початковий зміст не змінюється, а додається блок даних, так званий «Електронний цифровий підпис». Отримання цього блоку можна розділити на два етапи:

На першому етапі за допомогою програмного забезпечення i спеціальної математичної функції обчислюється так званий «відбиток повідомлення» (англ. message digest). Цей відбиток має такі властивості:

фіксовану довжину, незалежно від довжини повідомлення;

унікальність відбитку для кожного повідомлення;

неможливість відновлення повідомлення за його відбитком.

Таким чином, якщо документ був модифікований, то зміниться і його відбиток, що відобразиться при перевірці Електронного цифрового підпису.

На другому етапі відбиток документу шифрується за допомогою програмного забезпечення і особистого ключа автора. Розшифрувати ЕЦП i одержати початковий відбиток, який відповідатиме документу, можна тільки використовуючи Сертифікат відкритого ключа автора. Таким чином, обчислення відбитку документу захищає його від модифікації сторонніми особами після підписання, а шифрування особистим ключем автора підтверджує авторство документу.

Електронний цифровий підпис (ЕЦП) (англ. digital signature) - вид електронного підпису, отриманого за результатом криптографічного перетворення набору електронних даних, який додається до цього набору або логічно з ним поєднується і дає змогу підтвердити його цілісність та ідентифікувати підписувача. Електронний цифровий підпис накладається за допомогою особистого ключа та перевіряється за допомогою відкритого ключа.

Одним із елементів обов'язкового реквізиту є електронний підпис, який використовується для аутентифікації автора та/або 
підписувача електронного документу іншими суб'єктами електронного документообігу.

Оригіналом електронного документа вважається електронний примірник з електронним цифровим підписом автора [1].

Висновок. На основі проведених досліджень, можна впевнено зазначити, що впровадження електронного (автоматизованого) документообігу та електронного цифрового підпису, сприяє значному підвищенню ефективності організації облікового процесу на підприємстві, що забезпечує оперативне генерування достовірної облікової інформації.

\section{Список використаних джерел:}

1. Електронний документ. Вікіпедія. [Електронний ресурс]. Режим доступу - https://uk.wikipedia.org/wiki/\%D0\%95\%D0\%BB\%D0\%B5\%D0\%B A\%D1\%82\%D1\%80\%D0\%BE\%D0\%BD\%D0\%BD\%D0\%B8\%D0\%B9_\%D0 \%B4\%D0\%BE\%D0\%BA\%D1\%83\%D0\%BC\%D0\%B5\%D0\%BD\%D1\%82.

2. Плаксієнко В. Я. Концептуальні основи організації безпаперової бухгалтерії / Плаксієнко В. Я., Назаренко І. М. // Агросвіт. - 2018. - № 12. - C. 3-7.

3. Закон України Про електронні документи та електронний документообіг від 22.05.2003 № 851-IV [Електронний ресурс] - Режим доступу: http://zakon3.rada.gov.ua/laws/show/851-15.

4. Назаренко I. М. Нормативно-правове регулювання безпаперової бухгалтерії / I. М. Назаренко // Причорноморські економічні студії : економічний науково-практичний журнал. - Одеса, 2018.

\section{REFERENCES:}

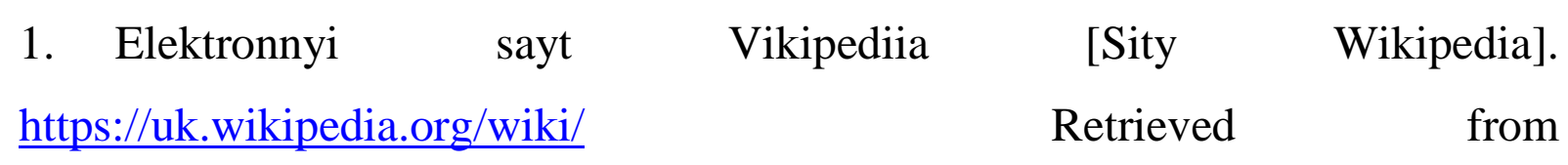
https://uk.wikipedia.org/wiki/\%D0\%95\%D0\%BB\%D0\%B5\%D0\%BA\%D1\%82 
\%D1\%80\%D0\%BE\%D0\%BD\%D0\%BD\%D0\%B8\%D0\%B9 \%D0\%B4\%D0\% BE\%D0\%BA\%D1\%83\%D0\%BC\%D0\%B5\%D0\%BD\%D1\%82. [in Ukranian]. 2. Plaksiienko V. Ya., Nazarenko I. M. (2018). Kontseptualni osnovy orhanizatsii bezpaperovoi bukhhalterii [Conceptual foundations of organization of paperless accounting ]. Ahrosvit. - AgroSvit, 12. [in Ukranian].

3. Zakon Ukrainy Pro elektronni dokumenty ta elektronnyi dokumentoobih [Law of Ukraine on electronic documents and electronic document circulation]. (n. d.). $\quad$ https://zakon.rada.gov.ual

Retrieved from http://zakon3.rada.gov.ua/laws/show/851-15 [in Ukranian].

4. Nazarenko I. M. (2018). Normatyvno-pravove rehuliuvannia bezpaperovoi bukhhalterii [Normative-legal regulation of paperless accounting]. Prychornomorski ekonomichni studii: ekonomichnyi naukovo-praktychnyi zhurnal - Black Sea Economic Studies: Economic Research and Practical Journal, Odesa, 2018. [in Ukranian].

(C) Плаксієнко В.Я., Черненко К.В. 